\title{
EFFECT OF DIABETES AND INSULIN ON THE ACTIVITY OF MYOCARDIAL AND ADIPOSE TISSUE LIPOPROTEIN LIPASE OF RATS *
}

\author{
By JACQUES I. KESSLER $\dagger$
}

(From the Department of Medicine and the Nutrition Laboratory', The Mount Sinai Hospital, New York, N.Y.)

(Submitted for publication August 27, 1962; accepted November 15, 1962)

Lipoprotein lipase (LPL), which specifically hydrolyzes the triglyceride component of chylomicrons and other low density lipoproteins (1), has been shown to be present in highest concentration in adipose and myocardial tissues (2).

Recently, it has been demonstrated that the activity of this enzyme in the tissues is greatly influenced by the nutritional state of the animal. Fasting produced a reduction of the activity of LPL in adipose tissue of rats which was restored to normal either by the administration of glucose one hour prior to sacrifice (3), or by pre-incubation of the tissue in the presence of glucose and insulin (4). The activity of myocardial LPL, on the other hand, was found to increase with fasting (5).

These findings would suggest that the activity of LPL in peripheral tissues may be dependent not only on the amount of carbohydrate available, but also on the ability of the animal to utilize carbohydrate. Thus, it is of interest to determine the influence of diabetes and insulin on the activity of myocardial and adipose tissue L.PL.

\section{METHODS}

The animals used in these experiments were young male rats of the Sprague-Dawley strain, weighing 200 to $250 \mathrm{~g}$. Three different groups of ten animals each were studied. The control group consisted of normal animals, the second group of untreated diabetic animals, and the third group of diabetic animals treated with insulin. Diabetes was induced in Groups II and III by an intracardiac injection of alloxan $(50 \mathrm{mg}$ per $\mathrm{kg}$ ), which invariably produced an overt diabetic state within 2 to 3 days. A daily dose of 8 to 15 units $\mathrm{NPH}$ insulin ${ }^{1}$ ad-

* Supported in part by grants H-564 and H-982 from the National Institutes of Health, U. S. Public Health Service.

$\dagger$ Present address: Dept. of Medicine, Jewish General Hospital, Montreal 26, Canada.

${ }^{1}$ Neutral protein Hagerdorn Iletin, $40 \mathrm{U}$ per milliliter, Eli Lilly and Co., Indianapolis, Ind. ministered subcutaneously was sufficient for a satisfactory control of the diabetes in Group III. The animals were individually housed in metabolic cages and had free access to food (Purina chow pellets) and water.

The glucose concentration in the urine was determined daily in 24-hour urine collections. Blood glucose was determined prior to the induction of diabetes and on at least two occasions after diabetes was established or after treatment with insulin was started. Blood glucose was determined according to Nelson's colorimetric method as modified by Somogyi (6). The diabetes was considered to be satisfactorily controlled only after two normal blood glucose levels were obtained and the urine contained no or only traces of glucose. Each animal was observed for a period of a week after diabetes was established or a satisfactory control of the diabetes was achieved. During this period of observation, two animals of the untreated and one animal of the treated group died. They were replaced with new animals that were observed for the same length of time.

The animals were lightly anesthetized with ether and sacrificed by an abrupt blow on the head. The two epididymal fat bodies and the heart were quickly excised, washed in ice-cold saline, and cut in approximately equal halves with sharp scissors. The contralateral distal and proximal halves of the epididymal fat bodies and one of the longitudinal halves of the heart from the animals of each group were pooled for determination of the LPL activity in acetone-dried epididymal fat and myocardial powder according to the method of Korn (7). The acetone-dried tissue residue was weighed and extracted with $0.025 \mathrm{~N}$ ammonia ( $50 \mathrm{mg}$ of tissue residue to $1 \mathrm{ml}$ of ammonia solution) for 30 minutes at room temperature. The supernatant solution was lyophilized, and the powder was dissolved in saline from which samples were taken for determination of the lipolytic activity. The activity was assayed by the amount of free fatty acids (FFA) liberated from an activated triglyceride-lipoprotein substrate $(8,9)$. The activity was expressed in microequivalents of FFA per gram of protein of the saline-dissolved powder which were liberated during one hour of incubation at $37^{\circ} \mathrm{C}$ ( $\mu \mathrm{Eq}$ per $\mathrm{g}$ per hour).

The other halves of epididymal fat bodies and hearts of each animal were placed in separate 25-ml Erlenmeyer flasks, each containing $1 \mathrm{ml}$ of Krebs-Ringer phosphate buffer $(0.16 \mathrm{M}, \mathrm{pH} 7.4)$ per $100 \mathrm{mg}$ of wet weight of 
TABLE I

Heparin-released myocardial and adipose tissue lipolytic activity of normal, diabetic, and insulin-treated diabetic rats

\begin{tabular}{|c|c|c|c|c|c|c|c|c|c|c|c|}
\hline \multirow[b]{3}{*}{ Rat } & \multicolumn{3}{|c|}{ Normal } & \multicolumn{4}{|c|}{ Diabetic } & \multicolumn{4}{|c|}{ Insulin-treated } \\
\hline & \multirow[b]{2}{*}{$\begin{array}{c}\text { Blood } \\
\text { glucose }\end{array}$} & \multicolumn{2}{|c|}{ Lipolytic activity* } & \multirow[b]{2}{*}{ Rat } & \multirow[b]{2}{*}{$\begin{array}{c}\text { Blood } \\
\text { glucose }\end{array}$} & \multicolumn{2}{|c|}{ Lipolytic activity* } & \multirow[b]{2}{*}{ Rat } & \multirow[b]{2}{*}{$\underset{\text { glucos }}{\text { Blucese }}$} & \multicolumn{2}{|c|}{ Lipolytic activity* } \\
\hline & & $\begin{array}{c}\text { Epi- } \\
\text { didy- } \\
\text { mal } \\
\text { fat }\end{array}$ & $\begin{array}{c}\text { Myo- } \\
\text { car- } \\
\text { dium }\end{array}$ & & & $\begin{array}{c}\text { Epi- } \\
\text { didy- } \\
\text { mal } \\
\text { fat }\end{array}$ & $\begin{array}{l}\text { Myo- } \\
\text { car- } \\
\text { dium }\end{array}$ & & & $\begin{array}{c}\text { Epi- } \\
\text { didy- } \\
\text { mal } \\
\text { fat }\end{array}$ & $\begin{array}{c}\text { Myo- } \\
\text { car- } \\
\text { dium }\end{array}$ \\
\hline \multicolumn{4}{|c|}{$\mathrm{mg} / 100 \mathrm{ml}$} & \multicolumn{4}{|c|}{$m g / 100 m l$} & \multicolumn{4}{|c|}{$\mathrm{mg} / 100 \mathrm{ml}$} \\
\hline $\begin{array}{r}1 \\
2 \\
3 \\
4 \\
5 \\
6 \\
7 \\
8 \\
9 \\
10\end{array}$ & $\begin{array}{r}104 \\
80 \\
90 \\
69 \\
83 \\
112 \\
113 \\
108 \\
75 \\
96\end{array}$ & $\begin{array}{l}44.6 \\
38.5 \\
35.0 \\
42.0 \\
29.8 \\
35.0 \\
32.4 \\
28.9 \\
48.0 \\
36.5\end{array}$ & $\begin{array}{r}8.4 \\
10.2 \\
9.8 \\
12.2 \\
7.9 \\
8.4 \\
9.6 \\
11.5 \\
10.6 \\
9.8\end{array}$ & $\begin{array}{l}11 \\
12 \\
13 \\
14 \\
15 \\
16 \\
17 \\
18 \\
19 \\
20\end{array}$ & $\begin{array}{l}318 \\
448 \\
154 \\
160 \\
208 \\
160 \\
154 \\
185 \\
248 \\
264\end{array}$ & $\begin{array}{r}10.8 \\
14.6 \\
9.8 \\
12.5 \\
14.2 \\
10.0 \\
21.1 \\
11.4 \\
26.1 \\
22.6\end{array}$ & $\begin{array}{l}26.4 \\
19.3 \\
24.1 \\
25.6 \\
27.4 \\
20.2 \\
32.4 \\
20.1 \\
26.2 \\
29.0\end{array}$ & $\begin{array}{l}21 \\
22 \\
23 \\
24 \\
25 \\
26 \\
27 \\
28 \\
29 \\
30\end{array}$ & $\begin{array}{r}130 \\
88 \\
112 \\
94 \\
108 \\
69 \\
83 \\
124 \\
113 \\
45\end{array}$ & $\begin{array}{l}41.4 \\
40.0 \\
35.4 \\
30.4 \\
44.5 \\
29.6 \\
33.6 \\
31.5 \\
28.9 \\
32.4\end{array}$ & $\begin{array}{r}10.4 \\
12.6 \\
11.0 \\
9.8 \\
9.6 \\
10.3 \\
8.4 \\
13.2 \\
11.4 \\
9.4\end{array}$ \\
\hline $\begin{array}{l}\text { Mean } \\
\quad \pm \text { S.D. }\end{array}$ & $\begin{array}{l}93 \\
15.4\end{array}$ & $\begin{array}{r}37.0 \\
5.6\end{array}$ & $\begin{array}{l}9.9 \\
1.3\end{array}$ & $\begin{array}{l}\text { Mean } \\
\quad \pm \text { S.D. }\end{array}$ & $\begin{array}{r}229.9 \\
90.0\end{array}$ & $\begin{array}{r}13.3 \\
4.4\end{array}$ & $\begin{array}{r}25.1 \\
4.0\end{array}$ & $\begin{array}{l}\text { Mean } \\
\quad \pm S . D .\end{array}$ & $\begin{array}{l}96.6 \\
22.7\end{array}$ & $\begin{array}{r}34.8 \\
5.0\end{array}$ & $\begin{array}{r}10.6 \\
4.4\end{array}$ \\
\hline
\end{tabular}

* Lipolytic activity expressed in microequivalents of FFA per gram per hour.

tissue. Heparin ${ }^{2}$ was added to a final concentration of 30 $\mu \mathrm{g}$ per $\mathrm{ml}$ and the flasks were incubated under air at $37^{\circ} \mathrm{C}$ for one hour. At the end of the incubation, samples of each incubation medium were taken for determination of the heparin-released lipase activity. The lipolytic activity was determined according to the procedure described before $(8,9)$, and expressed in microequivalents of FFA liberated by $1 \mathrm{~g}$ wet weight of tissue during one hour of incubation.

Free fatty acids (FFA) were extracted according to the method of Dole (10) as modified by Trout, Estes, and Friedberg (11) and titrated by the method of Gordon (12).

Protein was determined by the method of Lowry, Rosebrough, Farr, and Randall (13).

All determinations were performed in duplicate.

\section{RESULTS}

Lipolytic activity released from adipose and myocardial tissue of normal rats on incubation in presence of heparin. Incubation of epididymal fat pads and myocardium in the presence of heparin resulted in release of significant lipolytic activity in the incubation medium (Table I). Incubation in the absence of heparin produced only a minimal elevation of the lipolytic activity of the medium.

In agreement with previously reported results (14), the lipolytic activity released from epididymal fat was much higher than the activity re-

${ }^{2}$ Liquaemin, 1,000 U.S.P. U per milliliter, Organon, Inc., West Orange, N. J. leased from myocardial slices. This difference, however, was not observed when the tissues were incubated in the absence of heparin. The lipolytic activity of the heparin-free incubation media of either adipose or myocardial tissue fell within a very narrow range $(1.1 \mathrm{mEq}$ FFA per $\mathrm{g}$ per hour \pm 0.8 ). Addition of heparin to the incubation medium after the epididymal fat or myocardial tissue was removed did not change the original lipolytic activity of the medium. This would suggest that heparin released the enzyme from its binding sites in the tissues, rather than that it acted as an activator of the enzyme liberated into the incubation medium in the absence of heparin.

Effect of diabetes and insulin on the heparinreleased lipolytic activity of myocardial and epididymal fat tissue. Marked changes of the lipolytic activity released by heparin from the heart and the epididymal fat bodies were demonstrated in the animals with untreated diabetes (Table I). There was a pronounced reduction of the activity released from epididymal adipose tissue, whereas the lipolytic activity released from myocardial slices was significantly greater than that of the normal animals.

Administration of insulin in doses sufficient to control the diabetes restored the lipolytic activity released by heparin from myocardial and epididymal fat tissue to normal (Table I). 
TABLE II

Effect of inhibitors on heparin-released myocardial and adipose tissue lipolytic activity

\begin{tabular}{lccc}
\hline & $\begin{array}{c}\text { Final con- } \\
\text { centration } \\
\text { of inhibitor }\end{array}$ & $\begin{array}{c}\text { Inhibition of lipolytic } \\
\text { activity* }\end{array}$ \\
\cline { 3 - 4 } Inhibitor & & $\%$ & $\begin{array}{c}\text { Adipose } \\
\text { dissue }\end{array}$ \\
\hline dium & $\%$ \\
Protamine & $20 \mathrm{mg} / \mathrm{ml}$ & 78 & 84 \\
NaCl & $1 \mathrm{M}$ & 69 & 57 \\
$\mathrm{NaF}$ & $0.2 \mathrm{M}$ & 6 & 4 \\
\hline
\end{tabular}

* These values represent single determinations. The coefficient of variation of replicate determinations in samples from the same incubation medium was $6.4 \%$.

Properties of the heparin-released myocardial and adipose tissue lipolytic activity as compared to those of $L P L$. As a means of demonstrating that the enzyme released by heparin from surviving myocardial and adipose tissues was identical or similar to LPL, the effect of some factors known to influence the activity of LPL (1) was investigated.

Since the optimal substrate of LPL is a lipoprotein-triglyceride complex, the effect of omitting serum, and hence lipoprotein, from the substrate on the heparin-released lipolytic activity was determined. The final volume, $\mathrm{pH}$, and concentration of albumin and triglyceride were the same in both instances. In the absence of serum from the triglyceride substrate, any of the heparin-containing incubation media exhibited less than $10 \%$ of the lipolytic activity determined in the complete lipoprotein-triglyceride complex.

Protamine sulfate and $1 \mathrm{M} \mathrm{NaCl}$, which are known inhibitors of LPL, also inhibited the ac- tivity of the heparin-released myocardial and adipose tissue lipase. Sodium fluoride, which inhibits the activity of pancreatic lipase but not of LPL, exhibited little or no effect on the lipolytic activity released by heparin (Table II).

Finally, in agreement with the results reported by Nikkilä (15) on the partial purification of LPL, calcium phosphate gel adsorbed the heparinreleased lipase completely. By subsequent elution with sodium citrate, good recovery of the partially purified enzyme was achieved (Table III).

Essentially similar results were obtained with enzyme released by heparin from myocardial and epididymal fat tissues obtained from both treated and untreated diabetic rats.

Lipolytic activtiy of acetone-dried powder of myocardium and epididymal fat pads obtained from normal, diabetic, and insulin-treated diabetic rats. Since the observed differences in the heparin-released lipolytic activity of the normal and diabetic rats might be due either to failure of heparin to release an irreversibly fixed enzyme, or to liberation in the incubation medium of an inhibitor or activator of the enzyme, the lipolytic activity of the acetone-dried, ammonia-extracted, and lyophilized powder was also studied (Table IV). The lipolytic activity of the acetone-dried preparation obtained from epididymal fat pads was much higher than the activity of the myocardial preparation, similar to the results with the lipolytic activity released by heparin. Furthermore, the changes of the activity determined in the acetone-dried preparations obtained from myocardial

TABLE III

Partial purification of heparin-released myocardial and adipose tissue lipolytic activity *

\begin{tabular}{|c|c|c|c|c|c|c|}
\hline \multirow[b]{2}{*}{ Fraction } & \multicolumn{3}{|c|}{ Myocardial lipase } & \multicolumn{3}{|c|}{ Adipose tissue lipase } \\
\hline & Activity† & Protein & $\begin{array}{l}\text { Specific } \\
\text { activity } \ddagger\end{array}$ & Activity† & Protein & $\begin{array}{c}\text { Specific } \\
\text { activity } \ddagger\end{array}$ \\
\hline & $\mu E q / m l / h r$ & $m g / m l$ & & $\mu E q / m l / h r$ & $m g / m l$ & \\
\hline $\begin{array}{l}\text { Original incubation } \\
\text { medium }\end{array}$ & 1.14 & 0.46 & 2.5 & 4.2 & 0.26 & 16.2 \\
\hline $\begin{array}{l}\text { Supernatant fluid from } \\
\text { gel adsorption }\end{array}$ & 0.2 & 0.21 & 1.0 & 0.4 & 0.18 & 2.2 \\
\hline Enzyme eluted from gel & 0.95 & 0.09 & 10.6 & 2.9 & 0.05 & 58.0 \\
\hline
\end{tabular}

* These values represent single determinations. The degree of enzyme purification was dependent on the age of the gel. The coefficient of variation of replicate determinations with the same gel batch was $11.4 \%$. Five ml of each tissue incubation medium was adsorbed with $0.5 \mathrm{ml}$ gel. The gel was washed with $0.1 \mathrm{M}$ sodium oxalate and the enzyme then eluted with $5 \mathrm{ml} 0.04 \mathrm{M}$ sodium citrate.

$\dagger$ Lipolytic activity expressed in microequivalents of FFA per $1 \mathrm{ml}$ of incubation medium per 1 hour of incubation. $\$$ Lipolytic activity per milligrams of protein. 
and epididymal adipose tissue were parallel to the changes of the heparin-released lipolytic activity produced by diabetes and by insulin (Table IV). Thus, one can infer that the lipolytic activity released by heparin reflects the absolute activity of the enzyme in the tissues, although the effect of inhibition or activation cannot be completely eliminated.

\section{DISCUSSION}

The experiments reported in this study show that alloxan-diabetes exerted a profound effect on the LPL activity of adipose tissue and myocardium. The enzymatic activity of adipose tissue decreased, whereas in the same animals, the activity of myocardial LPL was found to be markedly elevated. Administration of insulin to the diabetic animals restored the myocardial and adipose tissue LPL activity to normal.

The observed changes in the LPL activity in the tissues of diabetic rats parallel in direction the changes in the activity of the same enzyme in adipose $(3,4)$ and myocardial tissue $(5)$ of fasted animals. The enzymatic activity was restored to normal either by prefeeding (5), by administration of glucose 1 hour prior to sacrifice (3), or by incubation of the tissue in the presence of glucose and insulin (4).

It appears, therefore, that the activity of myocardial and adipose tissue LPL is influenced not only by the presence of a sufficient amount of carbohydrate, but also by the ability of the tissues to utilize carbohydrate. It can be assumed that for the maintenance of a normal LPL activity in adipose tissue not merely a positive caloric balance is required, but presumably a critical amount of carbohydrate must enter and be utilized by the cell, the latter being dependent on a sufficient supply of insulin. Whether insulin has also a direct action on the LPL activity of the tissues, independent of its effect on the metabolism of carbohydrate, remains to be elucidated.

The parallel changes in the lipolytic activity released by heparin and the activity of the acetonedried preparations suggest that the effect of diabetes and insulin administration is upon the concentration of the enzyme protein itself or of an integral part of the enzyme such as heparin (1618). Recently an insulin effect on mucopolysaccharide components of adipose tissue has been
TABLE IV

Lipolytic activity of acetone-dried preparations obtained from epididymal fat and myocardial tissue of normal, diabetic, and insulin-treated diabetic rats

\begin{tabular}{lccc}
\hline \hline & \multicolumn{3}{c}{ Lipolytic activity* } \\
\cline { 2 - 4 } & $\begin{array}{c}\text { Normal } \\
\text { rats }\end{array}$ & $\begin{array}{c}\text { Diabetic } \\
\text { rats }\end{array}$ & $\begin{array}{c}\text { Insulin- } \\
\text { treated } \\
\text { rats }\end{array}$ \\
\hline & & $\mu E q / g / m l$ \\
Epididymal fat & 1554.6 & 822.7 & 1362.2 \\
Myocardium & 425.1 & 1305.9 & 596.8
\end{tabular}

* These values represent single determinations. The coefficient of variation of replicate determinations in samples from the same incubation medium was $8.9 \%$.

described (19). The hexosamine and uronic acid levels of epididymal fat pads treated with insulin were elevated when compared to those of nontreated rats (19). Heparin, which is a mucopolysaccharide consisting of hexosamine and hexuronic acid molecules esterified with sulfuric acid (20), might also be affected by insulin. This assumption can provide an explanation for the decreased adipose tissue LPL activity of diabetic rats and its elevation after administration of insulin.

The factors responsible for the opposite effect of diabetes and insulin on the myocardial LPL activity remain to be elucidated. Whatever these factors, the changes produced are sufficiently striking to suggest that they may play an important role in the adaptation of the organism to conditions of inadequate carbohydrate supply or utilization, such as is due to fasting or diabetes.

Recent experimental evidence supports the hypothesis that hydrolysis of the circulating particulate triglyceride is an essential step preceding its uptake and utilization by the tissues $(21,22)$. It is believed that chylomicrons and other low density lipoproteins are removed from the blood stream mainly as intact particles, and their triglyceride moiety is subsequently hydrolyzed in the tissues, a reaction probably catalyzed by LPL. Hence, alteration of the activity of LPL in the tissues may well affect the uptake and distribution of triglyceride fatty acids (TGFA) derived from chylomicrons and low density lipoproteins.

Recent studies by Bragdon and Gordon (23) have shown that fasting produced profound alteration in the tissue distribution of $\mathrm{C}^{14}$-labeled chylomicron triglyceride. More of the label was 
found in the myocardium, and considerably less in the adipose tissue of the fasted animals. These changes parallel in direction the changes in myocardial and adipose tissue LPL activity induced by diabetes or fasting. It has been demonstrated that during fasting the FFA extracted and utilized by the heart could supply most of its energy requirements (24). Ballard, Danforth, Naegle, and Bing (25) have shown that in fasting animals a significant fraction of the myocardial energy could be derived from the oxidation of fatty acids, extracted by the heart mainly from the circulating triglyceride. Therefore, the demonstrated elevation of myocardial LPL activity would appear to be of primary importance whenever the energy supply of the heart becomes dependent on fats. The enzymatic changes occuring in the tissues of fasted and diabetic animals may represent a mechanism for diverting circulating TGFA from adipose tissue to the heart, thereby providing energy for the performance of its more vital function.

Very recently, it has been shown that exogenous FFA (26), as well as FFA mobilized from the depots (27), can be incorporated by the liver in the triglyceride moiety of very low density lipoproteins. In the light of these findings, it appears that LPL might be of importance, not only in the clearing of exogenous (chylomicron) triglyceride, but also in the tissue uptake and distribution of endogenous TGFA of very low density lipoproteins produced and released by the liver.

\section{SUMMARY}

1. The lipolytic activity of myocardial and epididymal fat tissue of normal, diabetic, and insulintreated diabetic rats was compared.

2. The lipolytic enzyme was released from the surviving tissues on incubation in the presence of heparin. Its properties were found to be similar to the properties of lipoprotein lipase. The enzymatic activity of myocardial and adipose tissue acetone-dried preparations paralleled the lipolytic activity released by heparin.

3 . In normal rats the lipoprotein lipase activity of adipose tissue was considerably higher than the activity of the myocardium.

4. Diabetes produced a decrease in the lipoprotein lipase activity of adipose tissue and a marked elevation of the myocardial lipase activity.
5. The possibility that the changes of the enzymatic activity in the tissues, produced by carbohydrate deficit, may represent a mechanism for diverting energy-rich fatty acids from the depots. to the heart is discussed.

\section{ACKNOWLEDGMENTS}

Acknowledgment is due to Dr. L. E. Schaefer for his. interest and encouragement during this study. Miss. Celia Perez provided valuable technical assistance.

\section{REFERENCES}

1. Korn, E. D. Clearing factor, a heparin-activated lipoprotein lipase. II. Substrate specificity and activation of coconut oil. J. biol. Chem. 1955, 215, 15.

2. Korn, E. D., and T. W. Quigley, Jr. Studies on lipoprotein lipase of rat heart and adipose tissue. Biochim. biophys. Acta (Amst.) 1955, 18, 143.

3. Robinson, D. S. The effect of changes in nutritional state on the lipolytic activity of rat adipose tissue. J. Lipid Res. 1960, 1, 332.

4. Hollenberg, C. H. Effect of nutrition on activity and release of lipase from rat adipose tissue. Amer. J. Physiol. 1959, 197, 667.

5. Hollenberg, C. H. The effect of fasting on the lipoprotein lipase activity of rat heart and diaphragm. J. clin. Invest. 1960, 39, 1282.

6. Somogyi, M. Notes on sugar determination. J. biol. Chem. 1952, 195, 19.

7. Korn, E. D. Clearing factor, a heparin-activated lipoprotein lipase. I. Isolation and characterization of the enzyme from normal rat heart. J. biol. Chem. 1955, 215, 1.

8. Kessler, J. I. Effect of Lipomul infusion on plasma lipolytic activity; characterization and partial purification of a post-Lipomul lipase and its role in changing the electrophoretic mobility of lipoproteins. J. Lab. clin. Med. 1962, 59, 558.

9. Kessler, J. I., and E. Senderoff. Effect of experimental infarction, manual massage, and electrical defibrillation on myocardial lipoprotein lipase activity of dogs. J. clin. Invest. 1962, 41, 1531.

10. Dole, V. P. A relation between non-esterified fatty acids in plasma and the metabolism of glucose. J. clin. Invest. 1956, 35, 150.

11. Trout, D. L., E. H. Estes, Jr., and S. J. Friedberg. Titration of free fatty acids of plasma: a study of current methods and a new modification. J. Lipid Res. 1960, 1, 199.

12. Gordon, R. S., Jr. Unesterified fatty acid in human blood plasma. II. The transport function of unesterified fatty acid. J. clin. Invest. 1957, 38, 810.

13. Lowry, O. H., N. J. Rosebrough, A. L. Farr, and R. J. Randall. Protein measurement with Folin phenol reagent. J. biol. Chem. 1951, 193, 265. 
14. Cherkes, A., and R. S. Gordon, Jr. The liberation of lipoprotein lipase by heparin from adipose tissue incubated in vitro. J. Lipid Res. 1959, 1, 97.

15. Nikkilä, E. A. Partial purification of clearing factor of postheparin human plasma. Biochim. biophys. Acta (Amst.) 1958, 27, 612.

16. Robinson, D. S. Further studies on the lipolytic system induced in plasma by heparin injection. Quart. J. exp. Physiol. 1956, 41, 195.

17. Korn, E. D. Inactivation of lipoprotein lipase by heparinase. J. biol. Chem. 1957, 226, 827.

18. Korn, E. D., and T. W. Quigley, Jr. Lipoprotein lipase of chicken adipose tissue. J. biol. Chem. 1957, 226, 833

19. White, J. E. First International Congress of Endocrinology, Copenhagen, 1960, p. 1297.

20. Krantz, J. C., Jr., and C. J. Carr. The Pharmacologic Principles of Medical Practice, 4th ed. Baltimore, Williams \& Wilkins, 1958, p. 961.

21. Fredrickson, D. S., and R. S. Gordon, Jr. Transport of fatty acids. Physiol. Rev. 1958, 38, 585.
22. Havel, R. J., and A. Goldfien. The role of the liver and extrahepatic tissues in the transport and metabolism of fatty acids and triglycerides in the dog. J. Lipid Res. 1961, 2, 389.

23. Bragdon, J. H., and R. S. Gordon, Jr. Tissue distribution of $\mathrm{C}^{14}$ after the intravenous injection of labeled chylomicrons and unesterified fatty acids in the rat. J. clin. Invest. 1958, 37, 574.

24. Man, E. B., and M. J. Albrink. Serum lipids in different phases of carbohydrate metabolism. Yale J. Biol. Med. 1956, 29, 316.

25. Ballard, F. B., W. H. Danforth, S. Naegle, and R. J. Bing. Myocardial metabolism of fatty acids. J. clin. Invest. 1960, 39, 717.

26. Havel, R. J. Conversion of plasma free fatty acids into triglycerides of plasma lipoprotein fraction in man. Metabolism 1961, 10, 1031.

27. Laurell, S. Recycling of intravenously injected palmitic acid-1-C $\mathrm{C}^{\mathbf{1 4}}$ as esterified fatty acids in the plasma of rats and turnover rate of plasma triglycerides. Acta physiol. scand. 1959, 47, 218. 